\title{
'Ecole et cinéma': A national model for arts education in schools
}

\author{
Perrine Boutin* - Université Sorbonne Nouvelle (Paris 3), France \\ Extract from Boutin (2010) \\ Translated from the French by Madeleine Whittle
}

\begin{abstract}
This essay presents the French educational programme 'Ecole et cinéma' in terms of its guiding principles. By examining the history of its creation, as well as the various levels at which this complex programme operates - from government agencies to pupils, by way of educators and organizational leadership - we begin to understand the identification processes and values that the programme advocates, along with the contradictions that situate this rigorous and high-quality programme as a national apparatus that is representative of a certain idea of arts education. But this is not without its own contradictions, which are inextricable from 'Ecole et cinéma', particularly at the present moment.
\end{abstract}

Keywords: school; cinema; identification; values; spectator

\section{Introduction}

'Ecole et cinéma' is a national programme that facilitates three to eight film screenings per year for groups of schoolchildren, ranging from pre-kindergarten to fifth grade.' Prompted by a memorandum that is circulated in schools, educators voluntarily enrol in the programme and commit to bringing their class to attend the programmed film screenings in a participating cinema. The programme is coordinated at the departmental level by 'cinema coordinators' - cinema owners, members of a trade group representing cinemas in the area and organizers from educational film festivals - and by 'national education coordinators', who provide departmental oversight. These coordinators are tasked with organizing screenings during school hours, and scheduling visits for classes whose teachers have chosen to enrol in the programme. They are also required to lead pre-screening discussions and teacher training sessions about film education in the classroom, as well as in-class workshops for pupils following the cinema film screenings. 'Ecole et cinéma' is an entity that relies on volunteer work - provided by the teachers who choose to enrol - which is not intended to be standardized, and is distinguished from simple classroom screenings thanks to the programming catalogue (containing a selection of 95 films in 2017/18, and increasing in scope annually), from which several titles are chosen to be screened over the course of the academic year.

The objective of this nationwide operation is to 'nurture the child-spectator through the active discovery of cinematic art, allowing young viewers and their teachers to discover high-quality films in theatrical venues, from pre-kindergarten through elementary school'. ${ }^{2}$ According to individuals most closely involved with 
'Ecole et cinéma', a pupil's encounter with a film is the most crucial moment in the process for the purpose of 'sparking a desire for cinema'. ${ }^{3}$ The end goal of their work is to bring this encounter to life; the bulk of the work deals with the remembered experience of the screening.

The cinema and the particular ambiance associated with projecting a film in a dark room are central to the programme's mission: the ritualized gathering, the public setting, the cocoon of darkness, 'the beam of light coming from behind one's head, the failing of one's motor skills, the gag over one's mouth, the mask over one's face' (Cornolli, 2000: 91-2) become the pedagogical site of initiation, a laboratory of learning. To paraphrase Georges Didi-Huberman (1995), one might say that the point of 'Ecole et cinéma' is to show that cinema can teach us to learn to see, to 'perform the work of seeing': a mode of seeing that obliterates perception - a passive observation of tautological reality - or rather, a mode of seeing that enlarges perception, that literally opens it up by bringing to bear a cognitive process, a perpetual interrogation. Hervé Joubert-Laurencin declared that 'to learn to see is to be the spectator of one's own gaze', ${ }^{4}$ insofar as 'to see is a creative act'. ${ }^{5}$

Les enfants de cinéma is the organization that coordinates 'Ecole et cinéma' at the national level. Its mission is of a different order. It performs an assessment of the programme by way of a questionnaire that is distributed to programme coordinators at the end of every school year. With the help of a national committee, it selects the films that are added to the catalogue each year - on average, two to four films annually. Each year, it convenes the 186 coordinators from 93 participating programmes, who converge for two-and-a-half days of conversations and symposia around a unifying theme. Les enfants de cinéma serves as an interface between the ministries overseeing the programme - Culture and Communication, and National Education and the departmental coordinators. For example, they regularly appeal to the CNC (Centre national du cinéma et de l'image animée) for supplementary grants, which are intended to be distributed to cinema coordinators by DRAC (Direction régionale des affaires culturelles). Likewise, the organization adjudicates potential disputes between coordinators. It plays the role of intermediary between 'the field' and 'the leadership', but also between the 'leaders' themselves, and sometimes between different parties 'in the field'. The employees of Les enfants de cinéma are directed to attend departmental meetings that often occur at the end or the beginning of the year, for purposes of assessment and programme selection for the following year. Finally, the group operates an online pedagogical platform called Nanouk (http://enfantsde-cinema.com/nanouk), which features film-related handouts, workbooks, DVDs, instructional materials intended for teachers, a series of textbooks (Cahiers de notes sur ..., each one dedicated to a different film) and postcards for pupils.

This programme is interesting to examine for several reasons. First, I regard it as emblematic of the organizational complexity that an educational initiative of this type requires. Indeed, it involves every level of the hierarchy of authorities - national, regional, departmental and local - as well as various administrative bodies within national education and cinematic institutions. Along these lines, 'Ecole et cinéma' is the most rigidly hierarchical programme of its kind, thanks to the existence of the intermediary organization Les enfants de cinéma. The other nationwide school programmes, 'Collège au cinéma' and 'Lycéens et apprentis au cinéma', are directly managed by the CNC, which performs the same functions as Les enfants de cinéma, and then delegates the work of coordinating the programmes to departmental and regional apparatuses for middle and high schools respectively, not unlike the nowdefunct regional centres for image-based education. ${ }^{6}$ Furthermore, the programme 
constitutes the most thoroughly institutionalized model of cinema education, insofar as it affects over 10 per cent of French schoolchildren - the slogan of 'Ecole et cinema' is 'the premier programme in arts education'.

This programme is the most fully realized instance of the institutionalization of arts education in France. I have identified three of its major characteristics, which I will elaborate here. First, it is marked by a contradiction: it is the only means available for establishing a curriculum's institutional legitimacy, but it is simultaneously in conflict with the idea of artisanal programming, adapted for a local environment. Second, there is perennial equivocation between the sense that expansion of the programme would be unmanageable, and the feeling that the growth of the programme is a point of pride. Finally, 'Ecole et cinéma' is a bastion defending the status of cinema as an art, distinct from its status as an audiovisual medium and as a culture industry.

\section{Genesis of a programme: The twin poles of national education and culture}

In 1992, the CNC commissioned a study from the director of a children's film festival and an art-house cinema to plan the implementation of a programme similar to 'Collège au cinéma' and 'Lycéens et apprentis au cinéma'. In the report that Ginette Dislaire (1993) submitted to the CNC about recent research in film education, the partnership between the ministries of Culture and National Education is presented as the founding basis for the programme that was then called 'Ecole et cinema, les enfants du Ile siècle'. The expression 'children of the second century' refers to the centenary of cinema, which was celebrated during the year of the creation of 'Ecole et cinema', in 1994/5.

Ginette Dislaire (ibid.) hypothesizes that the key to success resides in the convergence of these two ministries. In this vein, school leadership was enlisted from the start of the project. Before asking cinemas to complete a questionnaire in order to carry out the research commissioned by the CNC, a meeting was called with the head of schools. He was intrigued by the idea of launching such a programme, and especially at the prospect that he would be involved from the beginning. In order to identify 'resource persons' who would be recruited to work with cinemas in the various departments, the head of schools circulated a memo to the academic leadership for the purpose of appointing 'departmental coordinators', who would act as representatives of school leadership, cinemas participating in the pilot programme, ${ }^{7}$ and educators. The National Education Ministry was thereby able to ensure its involvement at every level of the implementation. Pilot cinemas and organizations, for their part, were assigned to a representative with whom they would select the films to be screened, the number of pupil participants and the preview trailers featured. Thus, the project began to take shape at the national level and the departmental level alike. Today, nearly thirty years after this planning process, the programme continues to function in much the same way, having as its basis a binary departmental organization. The cinema/national education pairing is one of the notable trademarks of 'Ecole et cinéma'.

This bipolarity is reproduced at every level. For example, the administrative council of the national organization Les enfants de cinéma consists of 20 people, 10 of whom work in or adjacent to the National Education Ministry, while the other half are professionals in the film industry - cinema owners, union representatives, filmmakers, academics. In addition, administrative oversight of the national organization is shared by the CNC - an agency of the Ministry of Culture and Communication and the DGESCO (Direction générale de l'enseignement scolaire) and the Canopé 
network - Ministry of National Education. These collaborations at different levels illustrate one of the fundamental characteristics of 'Ecole et cinéma'.

Thus, unlike other programmes implemented by the CNC, 'Ecole et cinéma' has its origins in an effort on the part of film-loving educators and cinema owners who, drawing on and reflecting upon their experiences, wanted to create a project based, initially, on existing practices, in order to develop them further via a new umbrella association that would be responsible for implementing and monitoring the programme. The name of the umbrella organization, Les enfants de cinéma, comes from a work titled Cet enfant de cinéma que nous avons été ('We were cinema's children') (Bergala and Bourgeois, 1993), which evokes the cinema as a foundational encounter of childhood. The organizational literature for 'Ecole et cinéma' is extensive and detailed, and was the subject of an extensive review process that resulted in a series of modifications in 2008. It is sometimes deemed overly restrictive and demanding. Nonetheless, one coordinator noted that 'at least we knew what we were getting into when we adopted the guidelines'. ${ }^{8}$ The guidelines for 'Collège au cinéma', in comparison, were less substantial and, for the most part, exclusively technical: 'they don't include any recommendations concerning aspects of the programme related to pedagogy or arts education. ${ }^{19}$

The Culture/National Education bipolarity and the history of the implementation of 'Ecole et cinéma' make it an effective vehicle for a rigorous conception of arts education - rigour that is often extolled and endlessly championed. The conjunction linking school 'and' cinema is thus institutionalized. What does this look like on the ground?

\section{School and cinema: Interrogating the connection}

With its very name, the programme is emblematic of the stakes evoked by this pairing. At first glance, one might think that the 'success' of 'Ecole et cinéma' was tied to its capacity to respond to the demands of a structure such as the school. ${ }^{10}$ The importance of the role of the National Education Ministry in the programme was reinforced with the implementation of an initiative in accordance with a classor institution-wide 'proposal', ${ }^{11}$ or else via the intermediary oversight conducted by DGESCO and regional administrators. The harmony that exists between cinema and the function of a classroom was evoked by an employee of Les enfants de cinema, who observed that cinema 'is perhaps an artistic form that is well-suited to the constraints of the classroom. ${ }^{12}$ Bernard Lahire (2004: 47) expands on this subject, suggesting that the activities favoured by children and adolescents are generally those that can be enjoyed in a group setting, such as music, television and film. To support his claim, Lahire cites François de Singly, who asserts that 'television and cinema prevail over literature thanks to the greater ease with which they foster conversations, and support ordinary sociability' (de Singly, 1993, cited in Lahire, 2004: 48). Thus an activity such as reading finds itself falling behind cinema, although 'reading is regarded as the most legitimate of all cultural practices' (Coulangeon, 2010: 35). Cinema sets itself apart, and might be the genre that is most well-adapted to the consolidation of a large-scale programme in a school setting, since it is the most attuned to the pupils' expectations. This analysis reinforces the idea of a vigorous exposure to images in the educational process, and the privileged position granted to cinematic art in the classroom since the inception of cinema at the end of the nineteenth century. The educational institution would thus be equally well adapted to the development of a large-scale programme and to the goal of democratization. 'Ecole et cinéma' is thus a kind of hybridization 
between the respective logics of school and of the broader culture. The school setting entails a 'captive audience' upon whom it can easily impose its legitimacy, whereas cinema is obliged to 'captivate an audience' (Lahire, 2004: 39). 'Ecole et cinéma', as its name indicates, is situated between these two logics. The audience - the pupils - are clearly defined, and their attention ready-made to be captivated.

\section{Teachers: The locus for actualization of policy}

Alas, the reality is not so simple. Aside from children, educators are the primary audience to whom the programme is addressed: without their willing enrolment, 'Ecole et cinema' would not exist. The teachers are often criticized by coordinators; notably, with the expansion of the programme, the latter feared that the implementation would proceed 'at two different rates, where 10 per cent of educators are energetic and proactive, and the other 90 per cent are passive. ${ }^{\prime 13}$ For example, one coordinator attested to the complicity of certain instructors: 'Over the last several years, a tight-knit core group has formed. These educators have emerged as film lovers and enthusiastic volunteers at the heart of our organization. ${ }^{14}$ But the existence of this 'tight-knit core group' would suggest that there are others who are not 'film lovers'. What is more, many participants say that the true cinephile teachers are retiring, and are being replaced with instructors who are not lovers of film, and are often characterized by a conformism that verges on neurosis. For example, Philippe Meirieu (2004: n.p.) alludes to this phenomenon in the context of an 'Ecole et cinéma' event:

I heard Laurend Godel describe what happens at IUFM:15 our young IUFM trainees, though their memory goes back no further than twenty years, and though their cinematic memory begins with Star Wars [1977], find that when they become teachers, they simultaneously adopt a kind of negation of their own knowledge of film.

Likewise, at a training session for teachers, the film-maker Emilie Deleuze, invited to speak about the pupil workshops that she leads, immediately adopted a normative rhetoric, describing what one's relationship to cinema 'should be': 'We should avoid assuming a transcendental relationship to auteur cinema, putting it on a pedestal while consigning cruder films to a lower plane. ${ }^{16}$ The instructors leading the training session impressed upon the teachers that they should not feel hung up in relation to a cinematic culture with which they are poorly acquainted. Others, on the contrary, considered the programme in a positive light with regard to its marginality: 'In fact, the real audacity of this programme is to exhibit such films in an institutional framework like the classroom, bringing them into a setting where they don't belong: that's what I like about the programme. ${ }^{\prime 17}$

The greatest fear of these organizers is rooted in a preconception attributed to teachers regarding a programme that involves unloading one's class for half of the school day. The films included in the catalogue are intended, at a minimum, to be debated in class following each screening, and to provide a degree of collective cultural enrichment. Numerous teachers recounted anecdotes related to this construction of a common body of cultural knowledge, most notably in classrooms with pupils from diverse backgrounds. For example, one film ${ }^{18}$ that tells the story of a little girl who sells a newspaper called Soleil during a significant portion of the film often produces interjections of 'Sun! Sun!' when the teacher draws a sun (in classes where children are accustomed to regular weather announcements), which in turn leads the whole class to break out in laughter, including the teacher. Beyond establishing a shared 
knowledge base - even if only in the context of the classroom - the goal is to foster an appreciation of cinematic material. One administrator who also teaches explained in these terms: 'What young person is familiar with George Raft nowadays? Not one. Why should they be?' (Gabaston, 2004: 4). ${ }^{19}$

According to the interviews and conversations that I was able to conduct, one issue unites all of the educators: they unanimously consider the 'Ecole et cinéma' programme to be indispensable to the mission of promoting an alternative to the haphazard consumption of audiovisual media. In many cases, the teachers' attachment to the programme is motivated by a desire to contend with an influx of audiovisual material. One teacher explained ${ }^{20}$ that she became involved with 'Ecole et cinéma' in the hope that her pupils 'would no longer be content to settle for television, as is often the case'. What is more, she suggested removing DVD players from the classroom, 'so that pupils learn not to settle for DVD-quality projection in school, and might even be inspired to reject the format elsewhere', while another teacher simply refuses to furnish his home with any audiovisual materials whatsoever - no 'devices for watching films' in his house, as he puts it. Another educator felt that 'Ecole et cinéma' is of great interest to pupils, 'especially in the context of the image-saturated society in which we currently live'. Yet another educator observed that what 'Ecole et cinéma' offers is 'vital, compared to what [the pupils] see on television'. She expanded on this idea to encompass the offerings in commercial cinemas: 'We don't currently find films of this quality in movie theatres. Or if we do, a degree of selectivity is required. In any case, the offerings for children today are rather impoverished on the level of imagination.' The teacher was thus able to take ownership of 'Ecole et cinéma', in the interest of legitimizing its role as a mediator between the influx of images to which children are subjected, and the authentically cinematic image.

Indeed, these instructors' rhetoric points to numerous strategies of differentiation. By insisting upon their desire to distance themselves from the category of audiovisual media, they are simply announcing themselves as enlightened mediators, intent on helping pupils navigate the mediated universe in which they are immersed. They likewise seek to distance themselves from a mass culture deemed degrading, and thus produce what Pierre Bourdieu (1976) called 'schemes of classification', insofar as they fall into the category of those who deploy a critical expertise that would allow them to distinguish between different types of images, and thereby to describe them critically. The lexical field employed in conversations with the educators interviewed implies an entire value system: terms such as 'television', 'series' or 'DVD' carry systematically pejorative connotations. One teacher made a clear distinction between 'cinema' and 'audiovisual media': 'I wanted them to actually go to the movie theatre, and not to merely watch DVDs in school.' Another distinguished between films 'to watch in a theatre' and those 'to watch on DVD', thereby gesturing at a symbolic valorization of the movie theatre: 'I went to see Passe-passe [2008]. ... That's one to watch on DVD', she added, to signify her negative assessment of the film. Another teacher emphasized the need to make pupils understand 'that there are ways of watching films other than watching on a tablet'. Thus, strategies of distinction emerge and enable teachers to publicize their preferences regarding the role of 'Ecole et cinéma'.

As professionals, educators construct their identity in terms of their otherness, in relation to other media. They distance themselves from the culture embodied by television, thereby seeking to disseminate a vision of the world that they deem more legitimate. This rhetoric allows them to draw symbolic valorization from the 'Ecole et cinéma' programme. The lexical field that they employ illustrates the system of classification thus internalized. A teacher might love cinema - 'I love film. I often 
see movies at the cinema' - but her method of approaching the subject conveys a desire to distance herself from mass consumption, of which television is the quintessential example.

\section{Polemics of representation}

This discourse is frequently extended to include organizers, who voluntarily step into the role of theoreticians on the subject of educational programmes, analysing their successes but also their failures. Among the interviews conducted, this example was striking:

['Ecole et cinéma'] is not synonymous with entertainment, it's not about simply having a good time. And we are not in favour of screening the films again in a classroom setting, on DVD; this would be unfaithful to the spirit of the cinematic encounter in its true dimensions. ${ }^{21}$

Here, as in the rhetoric of educators, the temporal and spatial elements of the cinematic image are well-defined: film projection in a cinema is the sole means of fostering an 'encounter'22 with such an image 'in its true dimensions'.

We find the same rhetoric of expertise again on the part of pupils, notably in the context of film screenings. It is standard to observe children, as young as 4 years old, raise a hand to say: 'I have [the film] on DVD', or 'my grandmother already showed me that'. Sometimes the pupil will describe the audiovisual infrastructure with which their own households are outfitted: 'I have a 16:9 TV', or even 'I have a TV in my bedroom.' These kinds of interjections sometimes arise at a moment when the presenter is in the process of explaining that the format of the film that they are going to watch (or have watched) will be (or was) different from the films with which the pupils are accustomed - 4:3 format for the majority of older films. However, the pupil frequently expresses such observations in a way that is entirely incongruous, when the presenter asks if the children have questions about the film, at the end of the screening, as though to accentuate their own knowledge. Likewise, pupils accustomed to participating in the programme develop a vocabulary around the cinema itself, reflexively. For example, upon visiting a projection room, an upper-level elementary pupil immediately announced that 'This theatre [an art-house cinema associated with 'Ecole et cinéma'] shows films in black, white and grey, whereas the Rex [a nearby cinema exhibiting more 'commercial' films, not participating in 'Ecole et cinéma'] shows films in colour.' Thus, even at an early age, pupils develop a knowledge of screen culture, encompassing all formats, but with a clear distinction between the different types of films and their particular spatial and temporal qualities.

\section{Conclusion}

This project is emblematic of a certain model of image-based education in France, increasingly critiqued in France by theoretical approaches drawing on cultural theories in favour of abolishing the distinction ${ }^{23}$ between different media. Here cinema is privileged as an art form that must be experienced in its 'natural setting', ${ }^{24}$ the cinema, so that primary school pupils can be introduced to films under optimal conditions.

In autumn 2018, Les enfants de cinéma will assume leadership of the project 'Collège au cinéma'. Indeed, the CNC has directed the organization that operates the programme at an elementary level to replicate its model at the intermediary level. The latter age group has not benefited from the same history of collaboration between 
advisers from the National Education Ministry and from the film industry, and a number of significant operational discrepancies are evident. ${ }^{25}$ The objective is to restore a degree of homogeneity in order to establish a coherent identity for 'Collège au cinéma' across the entire territory. There is also a question of formalizing the experimental programme instated four years ago by Les enfants de cinéma for preschool pupils: 'Ecole et cinéma maternelle'. These two major changes will transform the ever-controversial organizational structure of the programme, but ultimately demonstrate that the institutions in question recognize the operational successes of 'Ecole et cinéma'.

\section{Notes on the contributor}

Perrine Boutin is a lecturer in the Department of Cinema and Audiovisual Studies at Université Sorbonne Nouvelle Paris 3. A member of the CNU division of information and communication sciences, she is affiliated with the Institut de recherche sur le cinéma et l'audiovisuel. She is co-chair of the master's programme Teaching the Image, vice-secretary of Les enfants de cinéma (the steering group at national level for 'Ecole et cinéma'), and president of Enfances au cinéma, which coordinates the programme in Paris and organizes the festival 'Mon premier cinéma'. Her work is concerned with cinema education, studying discourse and practice around cinematic mediation.

\section{Notes}

1 Cours Moyens 2 (CM2).

2 Excerpt from the official text introducing the programme.

3 Expression highlighted in the commemorative booklet published on the occasion of the ten-year anniversary of 'Ecole et cinéma'.

4 Excerpt from an interview conducted 3 December 2004 with an administrator for Les enfants de cinéma, author for the Cahiers de notes sur... series, and academic.

5 Remarks by the former cinema coordinator of the Paris department, 28 March 2005.

6 In autumn 2018, Les enfants de cinéma assumed organizational leadership over 'Collège au cinéma' (which had been falling behind in certain departments) in an effort to standardize the programme. I will return to this topic in the conclusion of the essay.

7 Today, this group consists primarily of cinema coordinators.

8 Excerpt from an interview conducted 23 March 2005 with the Cinema Coordinator for Côte d'Or, on the occasion of the ten-year assessment of 'Ecole et cinéma'.

9 Excerpt from an interview conducted 18 March 2005 with the National Education Coordinator for Somme, on the occasion of the ten-year assessment of 'Ecole et cinéma'. Since then, the 'Collège au cinéma' programme has modified its guidelines to more closely resemble those of 'Ecole et cinéma', although they remain significantly less detailed.

10 This is the thesis of Thomas Stoll (2008), whose work serves as the basis for this paragraph.

11 A class project.

12 Excerpt from an interview conducted 13 October 2007 with an employee of Les enfants de cinéma.

13 Excerpt from an interview conducted 13 October 2007 with an employee of Les enfants de cinéma.

14 Excerpt from an interview conducted 23 March 2005 with a cinema coordinator for the Gers, on the occasion of the ten-year assessment of 'Ecole et cinéma'.

15 IUFM (Institut universitaire de formation des maîtres) is the former name of ESPE (Ecoles supérieures du professorat et de l'éducation).

16 Excerpt from a talk by Emilie Deleuze, presented in a course titled 'Ecole et cinéma' at a training workshop for teachers, 7-9 November 2005.

17 Excerpt from an interview conducted 10 November 2004 with a CM2 schoolteacher.

18 La Petite Vendeuse de Soleil (1999).

19 George Raft was an American actor who had his heyday in the 1930s: he appeared in Howard Hawks's Scarface (1932), as well as in Billy Wilder's Some Like It Hot (1959). He is not widely known; I do not know whether this question was intended as a provocation.

20 The quotations that follow are drawn from a study conducted between 2008 and 2010 among 80 schoolteachers in Paris.

21 Excerpt from an interview conducted 31 May 2008 with a youth programme leader at the Cinémathèque française. 
22 Here we find the ideology of the 'aesthetic shock of the encounter', popularized in France by André Malraux.

23 I am using this term in reference to the work of Pierre Bourdieu (1979).

24 'Theatres, the natural setting for the discovery of cinema', excerpt from the organizational literature for 'Ecole et cinéma'.

25 An evaluation of the programme can be viewed at: http://enfants-de-cinema.com/evaluation/ college-au-cinema.

\section{Filmography}

Passe-passe (Off and Running, FR 2008, Tonie Marshall)

La Petite Vendeuse de Soleil (The Little Girl Who Sold the Sun, SN/FR/CH/DE 1999, Djibril Diop Mambéty)

Scarface (1932, Howard Hawks)

Some Like It Hot (US 1959, Billy Wilder)

Star Wars (US 1977, George Lucas)

\section{References}

Bergala, A. and Bourgeois, N. (eds) (1993) Cet enfant de cinéma que nous avons été. Aix-enProvence: Institut de l'Image.

Bourdieu, P. (1976) 'Un jeu chinois: Notes pour une critique sociale du jugement'. Actes de la recherche en sciences sociales, 2 (4), 91-101.

Bourdieu, P. (1979) La Distinction: critique sociale du jugement. Paris: Editions de Minuit.

Boutin, P. (2010) 'Le 7e art aux regards de l'enfance: Les méditations dans les dispositifs d'éducation à l'image cinématographique'. PhD thesis, Université d'Avignon.

Comolli, J.-L. (2000) 'Suspension du spectacle'. Images documentaires, 39, 91-8.

Coulangeon, P. (2010) Sociologie des pratiques culturelles. New ed. Paris: La Découverte.

de Singly, F. (1993) Les jeunes et la lecture (Les dossiers éducation et formations). Paris: Ministère de l'Éducation nationale et de la Culture.

Didi-Huberman, G. (1995) Ce que nous voyons, ce qui nous regarde. Paris: Editions de Minuit.

Dislaire, G. (1993) Etats des lieux des écoles et du cinéma juillet 92/décembre 93, CNC.

Gabaston, P. (2004) Bulletin des Enfants de cinéma, n³, octobre.

Lahire, B. (2004) La culture des individus: Dissonances culturelles et distinction de soi. Paris: La Découverte.

Meirieu, P. (2004) 'Images: De la sidération à l'éducation'. Conférence lors de la Rencontre nationale École et cinéma, Paris, 14-16 October 2004.

Stoll, T. (2008) Transmettre le cinéma à l'école - Le dispositif École et cinéma est-il vecteur de nouvelles modalités de transmission? Master's thesis, ESARTS. 